\title{
Influence of Agglomeration and Contamination in the Course of Amorphous Powder Grinding on Structure and Microstructure of Sintered Mullite
}

\author{
Stanislav Kurajica, ${ }^{\mathrm{a}, *}$ Emilija Tkalčec, ${ }^{\text {a Gordana Matijašić, }},{ }^{a}$

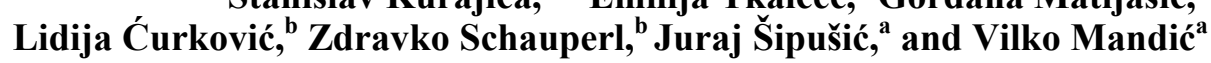 \\ ${ }^{a}$ Faculty of Chemical Engineering and Technology, University of Zagreb, \\ Marulićev trg 19, HR-10000 Zagreb, Croatia. \\ ${ }^{\mathrm{b}}$ Faculty of Mechanical Engineering and Naval Architecture, University of Zagreb, \\ Ivana Lučića 5, HR-10000 Zagreb, Croatia
}

RECEIVED JANUARY 13, 2010; REVISED JANUARY 19, 2011; ACCEPTED JANUARY 26, 2011

\begin{abstract}
The process of grinding of amorphous pre-mullite powder has been investigated. The powder has been obtained by sol-gel process followed by drying, calcination and wet milling in planetary ball mill for various periods. While particle size distributions shifts to finer size distributions as the grinding time increase, the specific surface area dependence on the grinding time shows complex behavior. This was attributed to the agglomeration in the course of calcinations partially promoted by slight re-esterification of the sample surface in the course of grinding. Mill wear debris has been observed in samples grinded for longer periods. The influence of particle size, re-esterification, agglomeration and contamination of samples on the mullite formation process, structure, sintering process and microstructure development, has been further investigated. Slight changes in samples phase composition, as well as mullite structure, and the great decrease of sintered body porosity with the duration of grinding have been observed. (doi: 10.5562/cca1662)
\end{abstract}

Keywords: Mullite, sol-gel process, grinding, sintering, microstructure

\section{INTRODUCTION}

Mullite is a solid solution with a general formula $\mathrm{Al}_{4+2 x} \mathrm{Si}_{2-2 x} \mathrm{O}_{10-x}$ where $\mathrm{x}$ represents the number of oxygen vacancies due to the composition-induced substitution of tetrahedral $\mathrm{Si}^{4+}$ by $\mathrm{Al}^{3+}$ (ref. 1). The high strength at high temperature, low thermal expansion, excellent creep resistance and good chemical and oxidation resistance make mullite an attractive ceramic material for advanced applications. ${ }^{2}$ For optical, structural and electronic applications ultra fine mullite precursor powders are of the utmost importance. ${ }^{3}$ In order to obtain highpurity mullite ceramics, the sol-gel process is employed. ${ }^{4}$ Premullite gels obtained by sol-gel procedure could be classified according to system homogeneity into two types: ${ }^{5}$ monophasic gels, with a molecular homogeneity and direct mullite crystallization from an amorphous phase at $\sim 980{ }^{\circ} \mathrm{C}$, and diphasic gels, inhomogeneous at molecular level, characterized with spinel phase crystallization at $\sim 980{ }^{\circ} \mathrm{C}$ and the mullite formation at temperatures higher than $1150{ }^{\circ} \mathrm{C}$. Before shaping, the dried and calcined gel particle size has to be reduced and there- fore, the processing of mullite often involves grinding. The theory of comminution process is based on crystalline materials while the comminution of amorphous materials and especially gels is far less investigated.

Therefore, the aim of this work was to provide information about the grinding treatment of amorphous diphasic pre-mullite powders. The dependence of the particle size distribution on the duration of grinding, as well as the influence of grinding process on structural evolution, the densification behavior and microstructure development has been investigated.

\section{EXPERIMENTAL}

Aluminum nitrate and tetraethoxysilane (TEOS) were used to prepare diphasic mullite gels that had overall alumina/silica weight ratio of 74/26 after heat treatment at $1600{ }^{\circ} \mathrm{C}$. The gel was prepared by dissolving $\mathrm{Al}\left(\mathrm{NO}_{3}\right)_{3} \times 9 \mathrm{H}_{2} \mathrm{O}$ (Kemika, Croatia) in $\mathrm{H}_{2} \mathrm{O}$ in molar ratio 1:28. The solution was stirred and refluxed at $60{ }^{\circ} \mathrm{C}$ for 1 day. TEOS, (Merck, Germany) previously

\footnotetext{
* Author to whom correspondence should be addressed. (E-mail: stankok@fkit.hr)
} 
mixed with ethanol (Kemika, Croatia) at molar ratio $1: 15$, and stirred at room temperature for 1 hour, was added dropwise to the aluminum nitrate solution. The mixture was stirred under reflux conditions at $60^{\circ} \mathrm{C}$ for 8 days. During this period the gelation is observed. The gel was dried under $150 \mathrm{~W}$ IR lamp for 1 day, further dried at $110{ }^{\circ} \mathrm{C}$ for 3 days in laboratory drier and then calcined at $700{ }^{\circ} \mathrm{C}$ for $4 \mathrm{~h}$ to decompose the organics and remove the volatiles. The calcined gel was manually crushed and ground in a corundum mortar, seized to particles smaller than $63 \mu \mathrm{m}$ and stored in a desiccator.

Calcined gel samples were grinded in planetary ball mill Fritsch $\mathrm{GmbH}$, Pulverisette 6 using $250 \mathrm{~mL}$ zirconia bowl and $30 \mathrm{ZrO}_{2}$ balls with $10 \mathrm{~mm}$ diameter with total weight of $\sim 70 \mathrm{~g} .10 \mathrm{~g}$ of premullite powder sample, mixed with $10 \mathrm{~mL}$ of isopropanol were grinded for $16,32,64,128,256$ and 512 min at revolution speed of $200 \mathrm{rpm}$. After grinding, the samples were dried under $150 \mathrm{~W}$ IR lamp for 1 day and calcined at $700{ }^{\circ} \mathrm{C}$ for $4 \mathrm{~h}$.

The particle size distribution of ground samples has been determined using particle size analyzer Coulter Counter ZM (Coulter Electronics Ltd.), in $\mathrm{NaCl}$ $(w=1 \%)$ aqueous solution previously filtered to eliminate background count. Two tests per sample were conducted and averaged values were reported.

Specific surface area of powders was determined by a Brunauer-Emmet-Teller (BET) $\mathrm{N}_{2}$ gas adsorptiondesorption isotherm obtained at $77 \mathrm{~K}$ on a Micromeritics ASAP-2000 equipment. Sample was previously degassed at $400{ }^{\circ} \mathrm{C}$ under a dynamic vacuum of $1.3 \times 10^{-2} \mathrm{~Pa}$.

The powders morphology was investigated with Scanning Electron Microscopy (SEM), TESCAN, VEGA TSS 136LS. Prior to scan, powders were applied to the adhesive graphite tape.

The thermal behavior of powder precursor was characterized with Differential Thermal Analysis (DTA) and Thermo-Gravimetric Analysis (TGA) using simultaneous DTA/TGA analyzer Netzsch STA 409. For the thermal analysis $\sim 100 \mathrm{mg}$ of material was placed in $\alpha$-alumina crucibles and heated at a rate of $10{ }^{\circ} \mathrm{C} \mathrm{min}^{-1}$ to $1350{ }^{\circ} \mathrm{C}$ in a synthetic air flow of $30 \mathrm{~cm}^{3} \mathrm{~min}^{-1}$, $\alpha$-alumina was used as a reference.

In order to establish the structural evolution with temperature, i.e. the path of crystallization, the samples were fired at $1000{ }^{\circ} \mathrm{C}, 1300{ }^{\circ} \mathrm{C}$ and $1600{ }^{\circ} \mathrm{C}$ for $4 \mathrm{~h}$ and studied by X-ray diffraction analysis (XRD) on difractometer Philips PW 1830 with $\mathrm{Cu}-\mathrm{K} \alpha$ radiation. Data were collected between 5 and $70^{\circ} 2 \theta$ in a step scan mode with steps of $0.02^{\circ}$ and counting time of $2 \mathrm{~s}$. For the purpose of mullite unit cell parameters determination, as well as for quantitative analysis, silicon was added as internal standard and data were collected between 10 and $120^{\circ} 2 \theta$ in a step scan mode with steps of

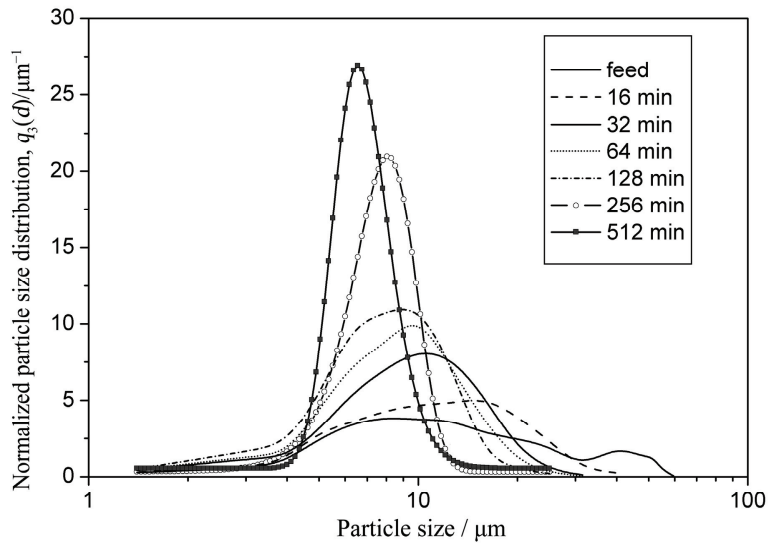

Figure 1. Particle size distributions of feed material and samples ground at different time periods.

$0.02^{\circ}$ and counting time of $10 \mathrm{~s}$. The initial values of the unit cell parameters obtained by Unitcell program ${ }^{6}$ were refined by whole powder pattern decomposition method, and quantitative analysis was performed by Rietveld method. The software TOPAS $2.1^{7}$ was used for both data evaluation.

The green compacts of premullite powders were obtained by uniaxial pressing (Paul Webber $\mathrm{GmbH}$ ) of 5 $\mathrm{g}$ of calcined sample in a die with diameter of $30 \mathrm{~mm}$ at a pressure of $100 \mathrm{MPa}$. Sintering was performed in a laboratory furnace at $1600{ }^{\circ} \mathrm{C}$ for $4 \mathrm{~h}$ in air.

The bulk density of coated sintered specimens was determined by the Archimedes method. Water was used as an immersion liquid.

Microstructure of the sintered samples was observed by Scanning Electron Microscopy (SEM), Philips XL 30. The samples were polished and thermally etched at $1550{ }^{\circ} \mathrm{C}$ for $30 \mathrm{~min}$.

\section{RESULTS AND DISCUSSION}

As shown in Figure 1, the particle size distributions of samples comminuted in planetary ball mill shift progressively to finer size distributions as the grinding time is increased. The shift in the size distribution curves is slightly better pronounced at low comminution duration. The shape of the size distribution curve of feed sample indicates two modal diameters, with further increase of grinding time the curves become monomodal reflecting samples monodisperse distribution.

Figure 2 illustrates changes of sample median size during comminution process at $200 \mathrm{rpm}$. With the increase of grinding time the product median size $\left(d_{50}\right)$ shifts toward smaller dimensions. This shift is more pronounced for shorter grinding times, prolonged grinding yields weaker effect, pointing out to the reduction of specific breakage rate and slowing down of the comminution process. The explanation for the slowing down of 


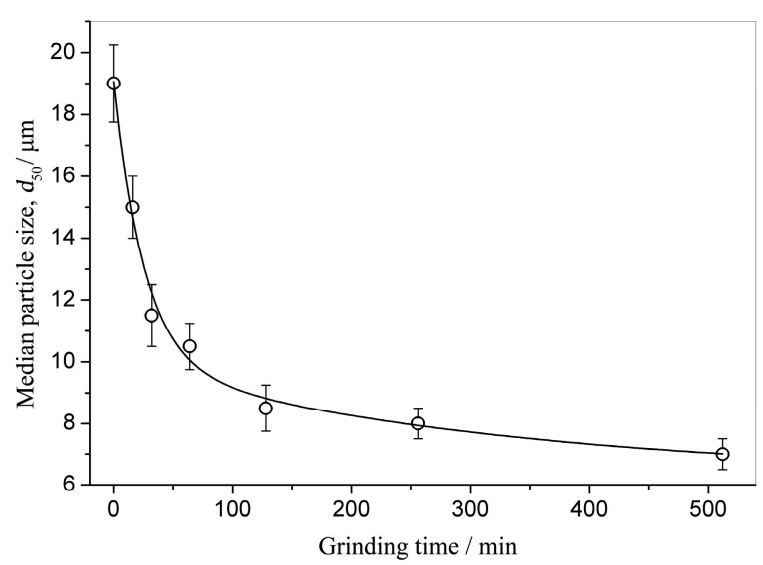

Figure 2. The change of median particle size $\left(d_{50}\right)$ of samples ground at different time periods. The zero time grinding indicates the feed size distribution. A line was introduced as a guideline for the eye.

comminution process could be found in more uniform stress distribution within the particles, obstructing the particle breakage, as well as the commencement of the agglomeration phenomena. With the increase of the grinding time, the constant particle size value was not attained. Taking into consideration that the difference between the product median particle sizes $\left(d_{50}\right)$ after 256 and $512 \mathrm{~min}$ was approximately $1 \mu \mathrm{m}$ it is very likely that prolonged grinding would not give significant additional effect. The obtained results corroborate well with those found by Amutharani and Gnanam ${ }^{8}$ which attained a constant particle size value $\left(d_{50}\right)$ of $8.5 \mu \mathrm{m}$ after $10 \mathrm{~h}$ of wet milling.

The surface area measurements have been carried out for the comminuted premullite powders calcined at $700{ }^{\circ} \mathrm{C}$ for $4 \mathrm{~h}$. Figure 3 shows the change in specific surface area of the feed sample and grounded samples obtained by BET measurements as a function of grinding time. One should expect the increase of surface area with the increasing duration of grinding i.e. with the decrease of the particle size, in fact quite the opposite trend occurs. To be more precise, the specific surface area dependence on grinding time shows complex behavior as presented in the Figure 3. While the particle size analysis was conducted on freshly grinded samples, without any further processing, the samples for the BET analysis were dried and calcined prior to analysis. Such processing is expected to provoke huge agglomeration of particles which, combined with the comminution gives rise to a complex dependence of SSA with grinding time. The final value of specific surface area, after $512 \mathrm{~min}$ of grinding yields $54 \mathrm{~m}^{2} \mathrm{~g}^{-1}$. J. Temuujin et al. ${ }^{9}$ also noted the decrease of specific surface area of the gels with grinding. They suggest that such behavior is a consequence of change in the surface of the gel from a porous to a monolithic state, i.e. the stuffing of micropores in the aggregated particles with the fine particles

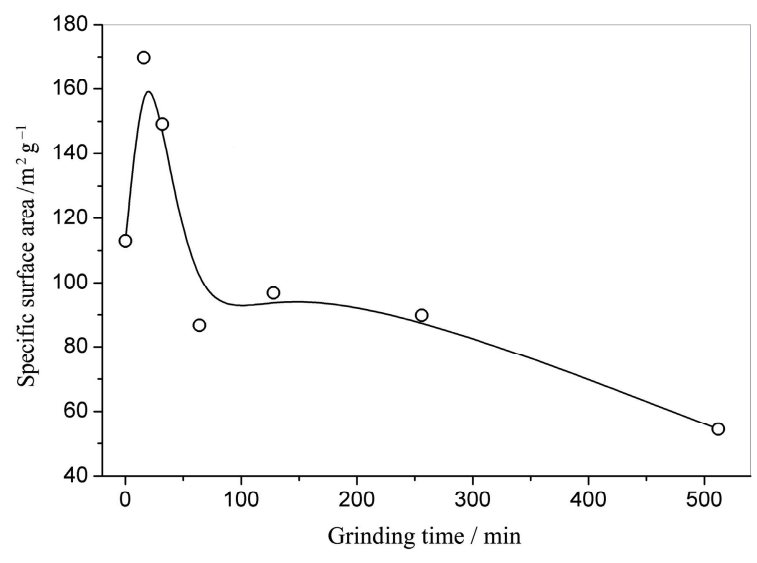

Figure 3. The BET specific surface area vs. grinding time. A line was introduced as a guideline for the eye.

introduced by grinding. Another effect significant for the interpretation of obtained results has been noted by Amutharani and Gnanam, ${ }^{8}$ they observed that the surface area rapidly decreased with the increase of calcination temperature, reflecting the negative effect of particle growth and aggregate formation. In their investigation a decrease of bulk density of the mullite compacts with the reduction of surface area was observed. Unfortunately, the utilization of calcination process at relatively high temperatures is unavoidable because low calcination temperatures can not provide sufficient volatilization of organics. The consequence would be great weight loss in the course of sintering, accompanied with the large shrinkage. This will lead to crack formation on the compacts during sintering due to the decomposition of the residuals. ${ }^{10}$ Therefore, in order to reduce the weight losses and avoid crack formation, the calcination temperature of the precursor powder should be above the decomposition temperature of organics.

For a detailed view of the size and morphology of the particles, SEM investigation of the powders was carried out. Figure 4 shows the SEM micrographs of the feed sample and powders milled for $128 \mathrm{~min}$ and 512 min. Feed sample as well as grinded samples are characterized with particles of irregular shape. As can be seen the particle size obtained by the Coulter counter roughly correlates with calcined powders particle sizes. On the other hand, for the ground powders large agglomerates can be found (Figures $4 c, 4 e$ and $4 \mathrm{f}$ ). In Figure $4 \mathrm{f}$ it is clearly observable that the agglomerates are composed of primary particles. Large inter-particle voids could be observed as well.

From the results of specific surface area measurement and SEM micrographs it is obvious that in the course of calcination process agglomeration occurs. In order to achieve high sintered densities it is essential to have starting powder as fine as possible, having specific surface area as great as possible, because the driving force for sintering is the reduction in surface energy. 

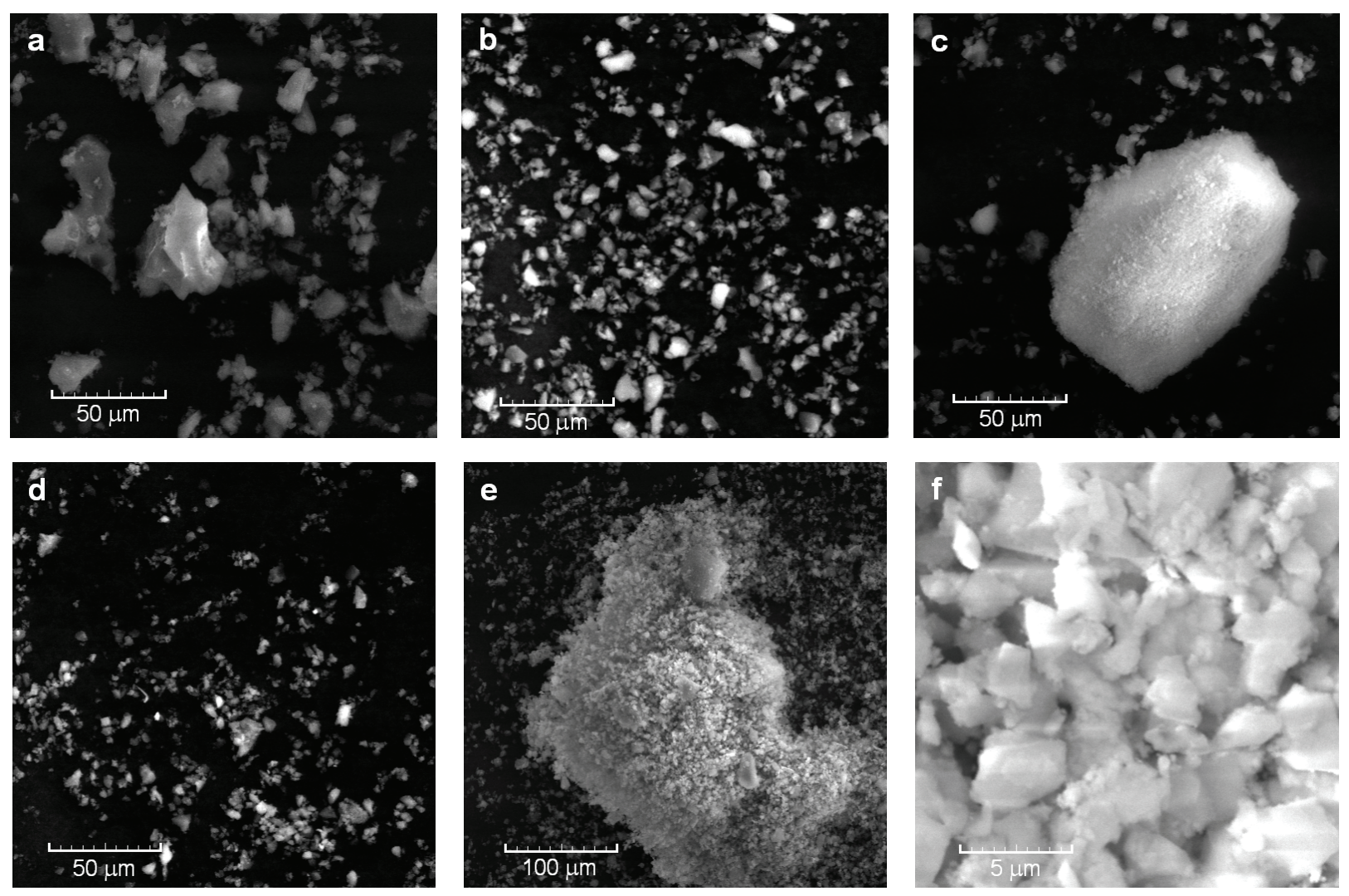

Figure 4. The SEM micrographs of gel powders milled for $0 \mathrm{~min}(\mathrm{a}), 128 \mathrm{~min}(\mathrm{~b}$ and c) and $512 \mathrm{~min}$ (d, e and f).

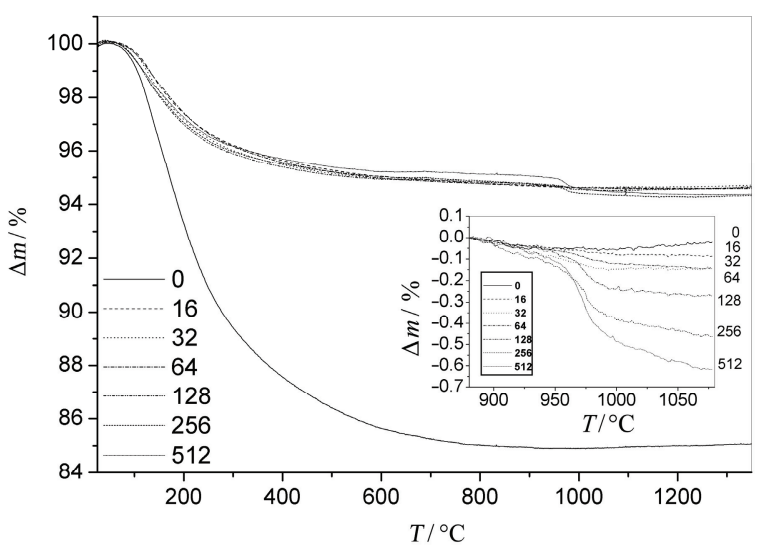

Figure 5. The TGA curves of premullite powder samples ground at various time intervals. Insert: enlarged curve segment in temperature interval between 880 and $1080^{\circ} \mathrm{C}$.

Unfortunately, fine powders often tend to agglomerate into particle cluster entities in order to achieve some reduction in surface energy. Agglomerates hinder flow properties and cause poor packing during die filling for compaction resulting in several types of defects in the green and sintered compacts ${ }^{11}$ decreasing green and sintered density.

The TGA curve of feed sample (Figure 5) show monotonic mass loss in temperature interval between room temperature and $\sim 900{ }^{\circ} \mathrm{C}$. The mass loss in this temperature interval is caused by dehydration, dehydroxylation and decomposition of nitrates and alkoxides and the evolving $\mathrm{CO}$ and $\mathrm{CO}_{2}$ formed by the combustion of organics. ${ }^{12}$ The total mass loss of feed sample between room temperature and $900{ }^{\circ} \mathrm{C}$ yields $\sim 15 \%$, while in temperature interval between 900 and $1350{ }^{\circ} \mathrm{C}$ the mass loss is negligible. Ground samples show far smaller mass loss (4-5\%) in the temperature interval between room temperature and $900{ }^{\circ} \mathrm{C}$, since these samples are calcined twice. But it is obvious that even double calcinations at $700{ }^{\circ} \mathrm{C}$, with total duration of $8 \mathrm{~h}$, do not cause complete removal of volatiles. The TG curves of grinded samples show additional weight loss at about $980{ }^{\circ} \mathrm{C}$. An enlarged plot of the TG curves of grinded samples in the interval $900-1100{ }^{\circ} \mathrm{C}$ is given as an insert overlay in Figure 5. The mass loss in this interval is roughly proportional to the duration of grinding and for the sample ground $512 \mathrm{~min}$ yields $\sim 0.7 \%$. A similar phenomenon has been noted by Schneider et $a{ }^{13}$ for coprecipitated mullite gel, by Temuujin et $a{ }^{9}{ }^{9}$ for diphasic gel ground for $20 \mathrm{~h}$ and by Tkalcec et al. ${ }^{14}$ for attrition ground diphasic gel. Temuujin et al. suggested that the delayed weight loss in the ground gel may be due to the trapping of $\mathrm{H}_{2} \mathrm{O}$, $\mathrm{NO}$ and $\mathrm{CO}_{2}$ in the small pores of densely-packed aggregates. ${ }^{9}$ Tkalcec et al. ${ }^{14}$ 
using mass spectra of gases evolved during thermal analysis found that this weight loss is due to a residual carbon oxidation followed by evolving of $\mathrm{CO}_{2}$ from the sample, and it is a consequence of re-esterification of sample surface in the course of grinding in alcohol media. Grinding particles in ethanol for $8 \mathrm{~h}$ causes cleavage of $\mathrm{Si}(\mathrm{Al})-\mathrm{O}-\mathrm{Si}$ bonds, the re-esterification of $\mathrm{Si}(\mathrm{Al})-\mathrm{O}-$ and the formation of $\mathrm{Si}(\mathrm{Al})-\mathrm{OR}$ units $\left(\mathrm{R}=\right.$ alcohol used as a grinding media). ${ }^{14}$ The latter decompose during thermal analysis at higher temperatures evolving the gaseous products. According to McKenzie et al. ${ }^{15}$ carbon, one of intermediate degradation products of gels organic residuals could be thermally stable under dynamic conditions to at least $900{ }^{\circ} \mathrm{C}$. Our efforts to confirm the existence of carbon in samples failed, on the other hand the grayish color of samples point out to presence of carbon traces. Therefore, the additional weight loss at about $980{ }^{\circ} \mathrm{C}$ is attributed to the evolution of $\mathrm{CO}_{2}$ due to a residual carbon oxidation.

The increase of mass loss at the $980{ }^{\circ} \mathrm{C}$ with the grinding time coincide with the decrease of BETdetermined specific surface area and the SEM-observable occurrence of a huge agglomerates. The most common type of agglomerate in a ceramic powder is one caused by a diffusion bond formed during calcination. In such, hard agglomerates the constituent particles are held by solid bridges, which are formed as a result of sintering, fusion, chemical reaction or setting of a binder. ${ }^{16}$ Re-esterification, if followed by additional hydrolysis and condensation could promote the particles agglomeration process.

The sample contamination introduced by grinding in zirconia bowl has been investigated using XRD. XRD patterns of samples thermally treated at $700{ }^{\circ} \mathrm{C}$ (calcinations) and $1000{ }^{\circ} \mathrm{C}$ for $4 \mathrm{~h}$ and grinded for 128 , 256 and 512 min are shown on Figure 6. While samples ground for less than $512 \mathrm{~min}$ are completely XRD amorphous, samples grinded for $512 \mathrm{~min}$ are characterized with the diffraction lines of cubic and monoclinic $\mathrm{ZrO}_{2}$. Zirconia entered the samples as wear debris from the milling bowl. XRD patterns of samples thermally treated at higher temperatures $\left(1000{ }^{\circ} \mathrm{C}\right.$ for $\left.4 \mathrm{~h}\right)$ revealed notable contamination even for sample grinded for $256 \mathrm{~min}$ (Figure 6). In this case the wear debris, which was XRD amorphous, crystallized in the course of thermal treatment. For the sample grinded for 512 min the diffraction lines of cubic and monoclinic $\mathrm{ZrO}_{2}$ are slightly stronger, also pointing out to additional crystallization process. The samples grinded for less than 256 min do not show XRD detectable contamination with zirconia. The contamination of intensively grinded samples with $\mathrm{ZrO}_{2}$ has been reported by Tkalcec et al. ${ }^{14}$ as well as Ismail et al. ${ }^{17}$ Both works consider that these phases do not influence the structure evolution of the powders during heat treatment, or its influence is negligible, the same is noted in this study.

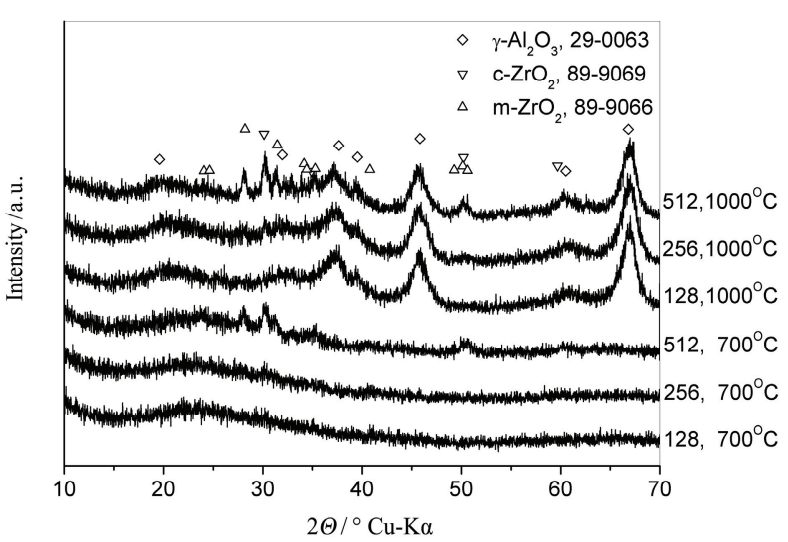

Figure 6. The Powder XRD patterns of samples thermally treated at 700 and $1000{ }^{\circ} \mathrm{C}$ for $4 \mathrm{~h}$, and ground for 128,256 and $512 \mathrm{~min}$.

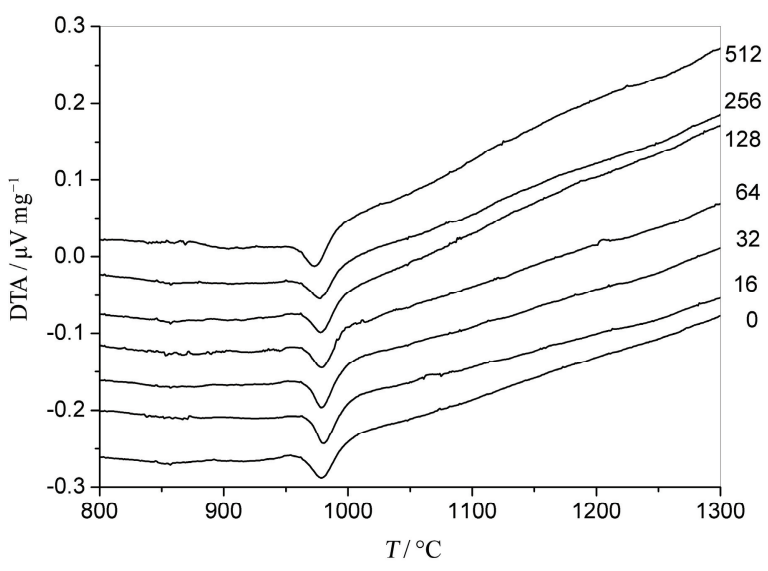

Figure 7. The DTA curves of premullite powder samples ground at various time intervals. The curves are shifted for visualization purpose.

The crystallization path of calcined premullite powders was examined by DTA. The DTA curve of asreceived sample prior to calcinations (not shown here) is characterized with the peaks in the low temperature range, caused by dehydration, dehydroxylation and decomposition of nitrates and alkoxides and the combustion of organics, ${ }^{12}$ which correspond to a great mass loss in this temperature range. The DTA curve is further characterized with exotherm at $\left(978{ }^{\circ} \mathrm{C}\right)$. The DTA scans of samples calcined at $700{ }^{\circ} \mathrm{C}$ for $4 \mathrm{~h}$, milled for various time and re-calcined are shown in Figure 7 . The low-temperature region peaks are reduced or completely missing and high-temperature peak is more pronounced due to an increased concentration (removing the organics) while its temperature shifts are negligible. No relevant shift of the exothermic peak with the increased duration of grinding was noted either. Interestingly, additional peak at $\sim 1200{ }^{\circ} \mathrm{C}$, expected for this type of gel $^{4}$ was not observed on DTA curves. The diphasic gel has no sufficient homogeneity for direct mullite forma- 


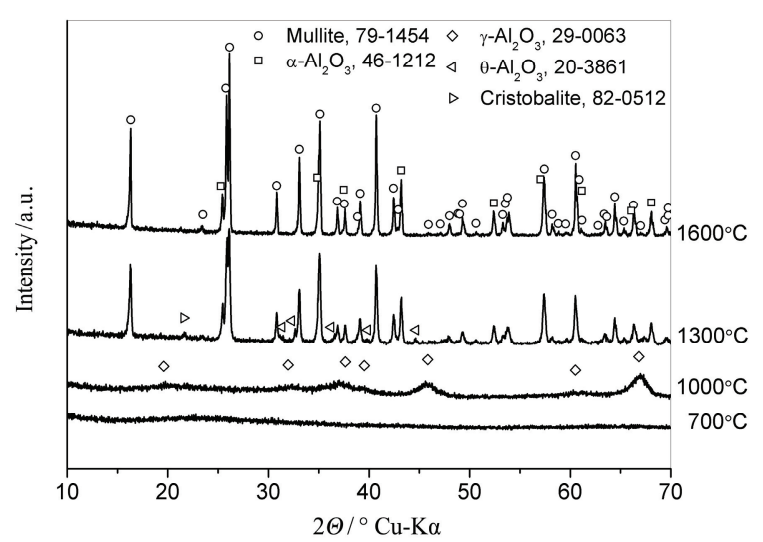

Figure 8. The powder XRD patterns of the feed sample thermally treated at various temperatures for $4 \mathrm{~h}$.

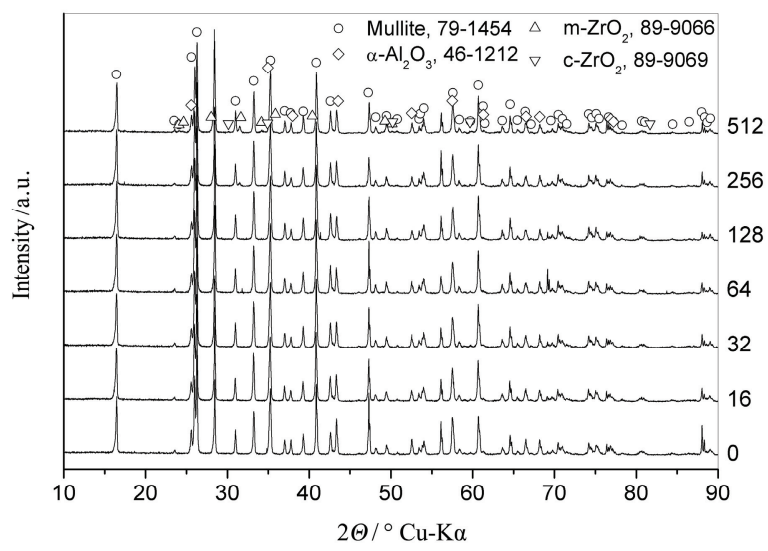

Figure 9. The powder XRD patterns of samples ground for various periods and fired at $1600{ }^{\circ} \mathrm{C}$ for $4 \mathrm{~h}$.

tion below $1000{ }^{\circ} \mathrm{C}$. Instead, primary crystallization of Al-Si spinel occurs followed by transformation to mullite at $\sim 1200{ }^{\circ} \mathrm{C},{ }^{18}$ both processes being visible on DTA scan as exothermic peaks. As shown later, by XRD analysis, the crystallization path of investigated samples is indeed typical for diphasic gel and the absence of second exothermic peak is a consequence of slow, lowenthalpy transformation process.

In order to assign the DTA exothermic events, the samples thermally treated for 4 hours at various temperatures were subjected to XRD analysis in order to establish the crystallization path of the gel. The XRD patterns of non-milled sample specimens are shown in Figure 8. Analysis reveals that the gel is amorphous up to the first exotherm on DTA curve at $977{ }^{\circ} \mathrm{C}$, after this point the XRD pattern displays typically broad reflections attributable to weakly crystallized aluminosilicate spinel. As evidenced by XRD, spinel phase transforms into orthorhombic mullite at temperatures below $1300{ }^{\circ} \mathrm{C}$. Although according to DTA curve the gel resembles type II, its thermal evolution corresponds to type III precursors according to Schneider's classification of formation

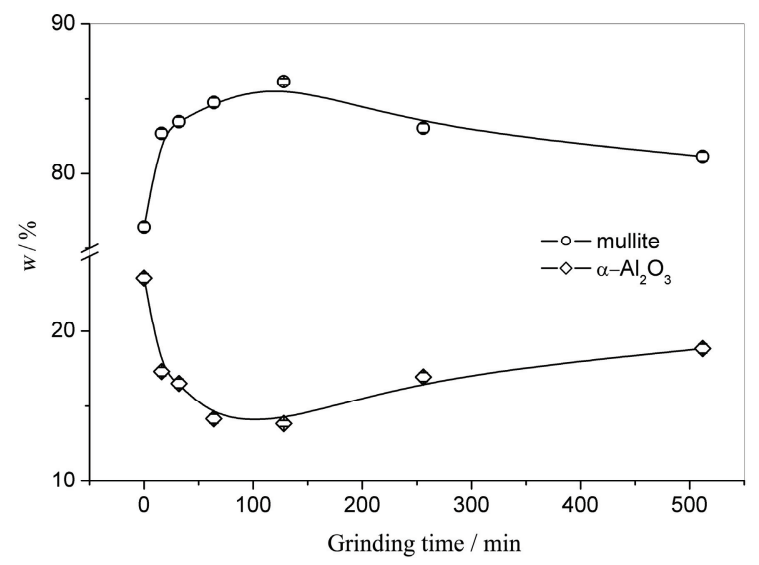

Figure 10. The dependence of mullite and $\alpha-\mathrm{Al}_{2} \mathrm{O}_{3}$ weight percent in samples fired at $1600{ }^{\circ} \mathrm{C}$ for $4 \mathrm{~h}$ on grinding time. Lines were introduced as a guideline for the eye.

paths. ${ }^{4}$ At $1300{ }^{\circ} \mathrm{C}$ and $1600{ }^{\circ} \mathrm{C}$ an $\alpha$-alumina peaks could be seen. That is the consequence of initial stoichiometry positioned in mullite+alumina phase field of $\mathrm{Al}_{2} \mathrm{O}_{3}-\mathrm{SiO}_{2}$ phase diagram.

Diffraction patterns of ground gels heated to various temperatures show no differences in crystallization path. Both calcined grounded and ungrounded gels are essentially amorphous, when heated at $1000{ }^{\circ} \mathrm{C}$, gels show evidence of the typically broad pattern attributable to a cubic spinel. Heating the gels to $1300{ }^{\circ} \mathrm{C}$ produces the crystallization of transient form of alumina $\left(\theta-\mathrm{Al}_{2} \mathrm{O}_{3}\right), \alpha-\mathrm{Al}_{2} \mathrm{O}_{3}$, and mullite. The latter two phases increase with thermal treatment at $1600{ }^{\circ} \mathrm{C}$ while $\theta-\mathrm{Al}_{2} \mathrm{O}_{3}$ transforms further to $\alpha-\mathrm{Al}_{2} \mathrm{O}_{3}$.

The XRD patterns of as-dried and ground diphasic gels thermally treated at $1600{ }^{\circ} \mathrm{C}$ for $4 \mathrm{~h}$ are shown in Figure 9. The XRD patterns differentiate by traces of contamination visible for samples grinded for 256 and $512 \mathrm{~min}$ and by the relative intensities of mullite and $\alpha$ $\mathrm{Al}_{2} \mathrm{O}_{3}$ peaks. Results of quantitative phase analysis (weight percents of mullite and $\alpha-\mathrm{Al}_{2} \mathrm{O}_{3}$ only) obtained by Rietveld method are presented in Figure 10. The increase of mullite and decrease of $\alpha-\mathrm{Al}_{2} \mathrm{O}_{3}$ quantity can be observed up to grinding time of $128 \mathrm{~min}$. Further grinding brought the opposite trend. Such behavior could be explained by combined influence of shortrange diffusion on one side and re-esterification on the other side. Mechanical treatment could enhance short range diffusion of species with consequent facilitation of chemical interaction. However, as argued before, sample median size $\left(d_{50}\right)$ shift toward smaller dimensions is more pronounced up to grinding time of 128 min. Also, as argued before, the agglomeration phenomenon was intensified with pronounced grinding which was linked with re-esterification phenomenon. The reesterification could also provoke phase separation if one species is preferentially re-esterificated. 


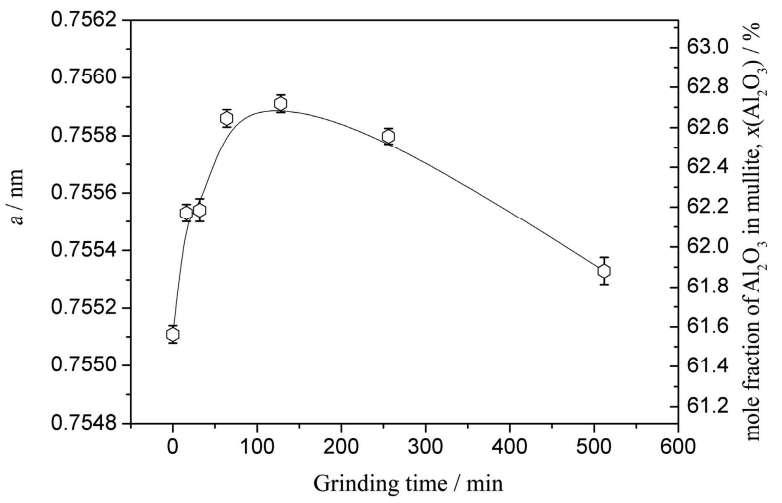

Figure 11. The Unit cell parameter $a$ of mullite in the samples thermally treated at $1600{ }^{\circ} \mathrm{C}$ for $4 \mathrm{~h}$ and the amount of $\mathrm{Al}_{2} \mathrm{O}_{3}$ in mullite calculated through the Ban and Okada ${ }^{19}$ equation $v s$. grinding time. Lines were introduced as a guideline for the eye.

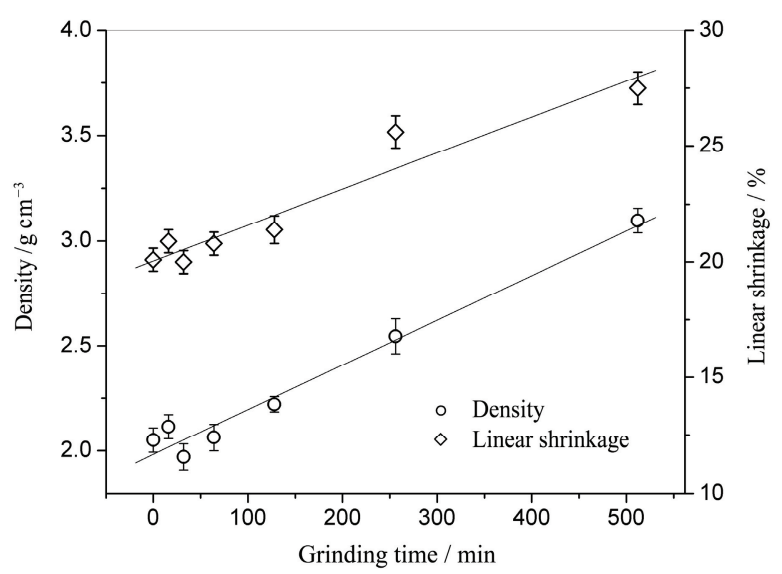

Figure 12. The dependence of linear shrinkage and sintered density on the grinding time.

The unit cell parameter $a$ of mullite in the samples thermally treated at $1600{ }^{\circ} \mathrm{C}$ for $4 \mathrm{~h}$ is presented as a function of grinding time in Figure 11. Exactly the same trend as with mullite weight percent can be observed with mullite unit cell parameters dependence on grinding time. The unit cell parameter $a$ of mullite lattice was related to mole fraction of $\mathrm{Al}_{2} \mathrm{O}_{3}\left(x\left(\mathrm{Al}_{2} \mathrm{O}_{3}\right) / \%\right)$ in mullite through the Ban and Okada ${ }^{19}$ relation:

$$
x\left(\mathrm{Al}_{2} \mathrm{O}_{3}\right) / \%=1443 \times a / \mathrm{nm}-1028.06
$$

As expected, the amount of $\mathrm{Al}_{2} \mathrm{O}_{3}$ in mullite is inversely proportional with the amount of $\alpha-\mathrm{Al}_{2} \mathrm{O}_{3}$ in sample due to the compensation of entrance of aluminium in mullite. The amount of $\mathrm{Al}_{2} \mathrm{O}_{3}$ in mullite is greatest for the sample grinded for 128 min (mole fraction, $x=62.72 \%$ ), the same sample has the smallest amount of $\alpha-\mathrm{Al}_{2} \mathrm{O}_{3}(w=13.84 \%)$ and the greatest amount of mullite $(w=86.16 \%)$.

The small particle size of the sol-gel powders was expected to provide an advantage for the densification behavior due to a larger surface energy, increased pack-


Figure 13. Micrographs of polished and thermally etched sections for a) feed sample and samples grinded for b) 128 and c) $512 \mathrm{~min}$, sintered in air at $1600^{\circ} \mathrm{C}$ for $4 \mathrm{~h}$.

ing density, reduced porosity and the enhancement of the neck formation in the initial sintering stage. A denser particle bed of the same particulate material is expected to yield better sintered product. ${ }^{20}$ On the other hand the agglomeration produces undesirable effects in ceramic processing by the decrease of green density and the sintered density. ${ }^{21}$

In Figure 12 the dependence of linear shrinkage and sintered density $v s$. the grinding time for the samples sintered at $1600{ }^{\circ} \mathrm{C}$ for $4 \mathrm{~h}$ is shown. The general trend of the increase of shrinkage and density with the increase of grinding time could be observed. The slight 
variations for the samples grinded for shorter time intervals could be observed but the discrepancies from general trend are within or close to error bars span. For the sample ground for $512 \mathrm{~min}$ and sintered at $1600{ }^{\circ} \mathrm{C}$ for $4 \mathrm{~h}$ the density yields $3.10 \mathrm{~g} \mathrm{~cm}^{-3}$ which is $97.8 \%$ theoretical mullite density $\left(3.17 \mathrm{~g} \mathrm{~cm}^{-3}\right){ }^{2}$ Taking into the consideration that samples contain certain amounts of alumina and zirconia the achieved percentage of theoretical mullite density is slightly smaller. Nevertheless, it is obvious that in this system the particles size have the decisive influence on the sintering efficiency. The enhancement of mullite sintering behavior by milling operations has been reported by the Amutharani and Gnanam, ${ }^{8}$ as well as Sacks and Pask. ${ }^{22}$

The SEM micrographs of feed sample and samples ground for 128 and $512 \mathrm{~min}$ are shown in Figure 13. It is obvious that the duration of grinding influences the microstructure to a great extent. The micrographs of feed sample and sample ground for 128 min are characterized with the isolated grains surrounded by pores. A closer inspection of grains reveals that they are composed of smaller, primary grains. As expected due to an almost theoretical density, sample ground for $512 \mathrm{~min}$ has far less pores. The microstructure shows very fine as well as large mullite grains, both being equiaxial which suggests dominancy of solid state sintering. That was expected since the weight ratio of prepared mullite is near the boundary between the mullite and mullitealumina phase fields in $\mathrm{Al}_{2} \mathrm{O}_{3}-\mathrm{SiO}_{2}$ equilibrium phase diagram (alumina rich). This suppresses the formation of $\mathrm{SiO}_{2}$-rich liquid phase and consequently liquid phase sintering process yielding anisotropic grain growth and occurrence of elongated mullite grains. ${ }^{23,24}$

\section{CONCLUSIONS}

The pre-mullite powder particle size distribution shifts to finer sizes as the grinding time increases. This shift is more pronounced for shorter grinding times. The shape of the size distribution curve of the feed sample presents several modal diameters. The curves of the samples ground for shorter periods are bimodal while curves of samples grinded for longer intervals become monomodal reflecting narrow distributions.

Specific surface area dependence on grinding time show complex behavior due to the agglomeration in the course of calcinations. The decrease of specific surface area at the prolonged grinding intervals has been noted. The agglomeration is confirmed by SEM of powder samples.

In the course of grinding in alcohol media slight re-esterification of the sample surface occurs. Carbon, an alcohol degradation product, remains in the sample until spinel crystallization temperature is reached. Cubic and monoclinic zirconia mill wear debris has been observed in the samples ground for 256 and $512 \mathrm{~min}$.
The crystallization behavior of mechanically treated diphasic gel is similar to that of type III mullite precursors. The ground gel converts to mullite via the spinel phase, some amount of $\alpha$-alumina also crystallizes. The mullite is alumina-rich in composition; changes in mullite composition and the amount of $\alpha$-alumina in sample, with the duration of grinding, have been noted. A sample ground for $128 \mathrm{~min}$ has the greatest amount of alumina in mullite and the smallest amount of $\alpha$-alumina.

The great enhancement of mullite sintering behavior by milling operation i.e. the increase of sintered density with the duration of grinding has been established. For the samples ground for $512 \mathrm{~min}$, the final relative bulk density of the sample sintered at $1600{ }^{\circ} \mathrm{C}$ for $4 \mathrm{~h}$ was $3.10 \mathrm{~g} \mathrm{~cm}^{-3}$. The duration of grinding influences the microstructure to a great extent. The SEM micrographs of sintered samples revealed that the feed sample and samples ground for shorter intervals are extremely porous while sample grinded for $512 \mathrm{~min}$ showed far less porosity. Equiaxial mullite grains points out to dominancy of solid state sintering.

Acknowledgements. The financial support of the Ministry of Science, Education and Sports of Republic of Croatia within the framework of the project: No. 125-1252970-2981 "Ceramic nanocomposites obtained by sol-gel process" is gratefully acknowledged.

\section{REFERENCES}

1. R. X. Fischer and H. Schneider: The mullite type family of crystal structures, in: H. Schneider and S. Komarneni (Eds.), Mullite, Wiley-VCH, Weinheim, 2005, p. 21.

2. I. A. Aksay, D. M. Dabbs, and M Sarikaya, J. Am. Ceram. Soc. 74 (1991) 2343-58.

3. H. Schneider, K. Okada, and J. Pask, Mullite and Mullite Ceramics, Willey, Chichester, 1994, p. 186.

4. H. Schneider, B. Saruhan, D. Voll, I. Merwin, and A. Sebald, J. Eur. Ceram. Soc. 11 (1993) 87-94.

5. S. Sundaresan and I. A. Aksay, J. Am. Ceram. Soc. 74 (1991) 2388-92.

6. T. J. B. Holland and S. A. T. Redfern, Mineral. Mag. 61 (1997) 65-77.

7. The software of TOPAS v2.1 of Bruker advanced X-ray solution. Karlsruhe, Germany: Bruker AXS; 2003.

8. D. Amutharani and F. D. Gnanam, Mat. Sci. Eng. A 264 (1999) 254-261.

9. J. Temuujin, K. Okada, and K. J. D. McKenzie, Ceram. Int. 25 (1999) 85-90.

10. F. Kara and J. A. Little, J. Eur. Ceram. Soc. 16 (1996) 627.

11. P. Balakrishna, B. Narasimha Murty, M. Anuradha, R.B. Yadav, and R. N. Jayaraj, J. Nucl. Mat. 150 (2005) 189-195.

12. E. Tkalčec, R. Nass, J. Schmauch, H. Schmidt, S. Kurajica, A. Bezjak, and H. Ivanković, J. Non-Cryst. Solids 223 (1998) 57-72.

13. H. Schneider, L. Merwin, and A. Sebald, J. Mater. Sci. 27 (1992) 805-812.

14. E. Tkalčec, D. Hoebbel, R. Nass and H. Schmidt, J. Non-Cryst. Solids 243 (1999) 233-234.

15. K. J. D. McKenzie, R. H. Meinhold, J. E. Patterson, H. Schneider, M. Schmuecker, and D. Voll, J. Eur. Ceram. Soc. 16 (1996) 1299. 
16. G. Y. Onada and L. L. Hench, Physical characterization terminology, in: G. Y. Onada and L. L. Hench (Eds.), Ceramic Processing Before Firing, John Wiley, New York, 1970, p. 36.

17. M. G. M. U. Ismail, Z. Nakai, and S. Somiya, J. Am. Ceram. Soc. 70 (1987) C7.

18. J. C. Huling and G. L. Messing, J. Am. Ceram. Soc. 74 (1991) 2374-2381.

19. T. Ban and K. Okada, J. Am. Ceram. Soc. 75 (1992) 227-230.

20. D. E. Niesz and R. B. Bennet, Structure and properties of agglo- merates, in: G. Y. Onada and L. L. Hench (Eds), Ceramic Processing before Firing, John Wiley, New York (1970), pp. 61-73.

21. P. Balakrishna, A. Singh, B. P. Varma, and P. Ramakrishnan, Interceram 44 (1995) 18-20.

22. M. D. Sacks and J. A. Pask, J. Am. Ceram. Soc. 6 (1982) 65-70.

23. T. Takei, Y. Kameshima, A. Yasumori, and K. Okada, J. Eur. Ceram. Soc. 21 (2001) 2487-93.

24. B. R. Johnson, W. M. Kriven, and J. Schneider, J. Eur. Ceram. Soc. 21 (2001) 2541-62. 